\title{
BILIK PADI TRADISIONAL KERINCI (Arsitektur dan Seni Ukir)
}

\author{
Nofrial $^{1}$, (nofcraft@gmail.com, nofrial@isi-padangpanjang.ac.id, Institut Seni Indonesia Padangpanjang) \\ Purwo Prihatin ${ }^{2}$ (Institut Seni Indonesia Padangpanjang) \\ Wahyono ${ }^{3}$, (Institut Seni Indonesia Padangpanjang) \\ Marten Agung Laksono ${ }^{4}$ (Institut Seni Indonesia Padangpanjang)
}

\begin{abstract}
Kerinci traditional bilik padi are no longer functioning, their existence is almost extinct. Through observation, literature studies and interviews, it is known that bilik padi use pedestal, a peg system in stringing poles. The entire building is made of wood, the building enlarges upwards. Octagonal pillars, sirap roofs, small doors made under the roof of the roof. The carving motif comes from the shape of plants, forms of vines. Engraving is applied to poles, walls, lower and upper beams, and end of rafter.
\end{abstract}

Keywords: Bilik Padi, Architecture and Carving Art

\section{ABSTRAK}

Bilik padi tradisional Kerinci sudah tidak difungsikan lagi, keberadaannya hampir punah. Melalui observasi, studi pustaka dan wawancara diketahui bilik padi menggunakan batu umpak, sistem pasak dalam merangkai tiang dengan balok. Seluruh bangunan terbuat dari kayu, bangunan membesar ke atas. Tiang segi delapan, atap sirap, pintu dibuat kecil dibawah bubungan atap. Motif ukiran berasal dari bentuk tumbuh-tumbuhan, bentuk sulur-suluran. Ukiran diterapkan pada tiang, dinding, balok bawah dan atas, serta ujung kasau.

Kata Kunci: Bilik Padi, Arsitektur dan Seni Ukir

\section{PENDAHULUAN}

Kerinci merupakan salah satu kawasan yang mempunyai kekayaan potensi budaya tradisional yang besar di Indonesia. Diantaranya ditunjukkan dengan banyaknya distribusi tinggalan artefak budaya masa lampau, salah satunya arsitektur tradisional Kerinci berupa lumbung padi, dalam istilah setempat disebut bilik padi. Bilik padi merupakan bagian tak terpisahkan dari pemukiman tradisional Kerinci dalam bentuk dusun dan luhah yang berlarik-larik, yang dibangun bersamaan dengan rumah Larik dan Masjid.

Bilik padi merupakan bangunan untuk menyimpan hasil pertanian, berupa padi dan komoditas lainnya untuk pangan. Bangunannya semi panggung atau di atas tiang (pille dwelling), struktur dan konstruksinya dari kayu, berbentuk empat persegi panjang, dengan konstruksi dinding melebar ke atas. Posisi bangunan secara umum menyesuaikan dengan posisi bangunan rumah larik, mengikuti aliran sungai, hulu ke arah hilir. 
Membujur dari Timur ke Barat menghadap ke Utara atau Selatan, atau membujur Utara ke Selatan menghadap ke Barat atau Timur (Nofrial, 2016, 1).

Sesuai peruntukannya, bilik padi berbeda dengan bangunan tempat tinggal rumah Larik. Bilik padi hanya terdiri dari satu ruang saja, serta pintunya kecil ditempatkan tinggi di bawah bubungan atap. Bilik padi dibangun di seberang jalan depan atau di belakang bangunan rumah larik. Penempatan bangunan bilik padi diatur sedemikian rupa, sehingga posisinya juga berderet seperti bangunan rumah Larik, tetapi antara satu bangunan bilik padi dengan bilik padi lainnya tidak tersambung seperti rumah Larik. Bangunan bilik padi di suatu dusun atau luhah terdapat beberapa buah. Jumlah ini sangat tergantung dengan jumlah anggota keluarga dan kemampuan ekonomi, luas lahan pertanian, terutama sawah yang dimiliki dari klebu dan tumbi tersebut. Pada satu Larik terdapat dua sampai enam bilik padi.

Bilik padi seperti rumah Larik dibuat dari kayu, termasuk atapnya, yang disebut atap sirap. Pada dinding, tonggak, tangga, serta balkon bilik padi ini diterapkan berbagai ukiran. Ukiran-ukiran yang diterapkan pada bilik padi ada yang merupakan turunan dari ukiran dari rumah Larik, ada juga yang dibuat khusus untuk bilik padi. Hal ini sesuai dengan peruntukan dan fungsi serta makna bangunan bilik padi di tengah masyarakat, sebagai penyimpanan bahan makanan; padi. Secara teknis pembuatan ukiran pada bilik pada mempunyai kesamaan dengan ukiran yang terdapat pada rumah Larik, dibuat dengan teknik ukir.

Seni ukir, bagian dari seni rupa yang terdapat dalam setiap kebudayaan dan kelompok masyarakat. Seni ukir di Kerinci yang salah satunya diterapkan pada bilik padi, keberadaannya tidak hanya bentuk pernyataan seni, akan tetapi merupakan manifestasi kehidupan masyarakat pendukungnya (Kayam, 1981/1982, 37). Bahkan kehadiran seni ukir menjadi sarana penting yang dapat memperlihatkan status sosial seseorang atau kaum, serta menjadi sarana legitimasi.

Ukiran pada bilik padi merupakan bahasa rupa, yang bernilai keindahan, berbentuk motif-motif yang diukir. Semua bentuk motif yang dirupakan selalu berkaitan erat dengan makna tentang ajaran adat istiadat dan norma yang berlaku di tengah masyarakat Kerinci. Di samping itu bilik padi atau lumbung itu sendiri sudah merupakan cerminan dan bukti akan status sosial dan kemampuan ekonomi dari pemiliknya. Karena memiliki lumbung padi menandakan kaum atau pemiliknya mampu secara ekonomi, apalagi sampai bilik padi tersebut berukir. Keterkaitan antara bilik padi dengan ukirannya merupakan simbolisasi dari kemampuan dan kemapanan ekonomi, teknik dan seni dari kaum dan pemiliknya.

Pada beberapa waktu terakhir bilik padi sudah tidak difungsikan seperti masa sebelumnya. Tradisi menyimpan padi setelah panen untuk jangka waktu lama udah hampir hilang dalam masyarakat Kerinci. Hal ini disebabkan karena perubahan pola kehidupan masyarakat dan kemajuan teknologi. Sehingga sudah dapat dipastikan hampir tidak ada lagi pembangunan bilik padi baru di Kerinci. Selain tidak ada pembangunan bilik padi yang baru, penggunaan dan perawatan terhadap bilik padi yang sudah adapun sudah tidak ada lagi, sehingga keberadaan bilik padi-bilik padi tersebut mulai hilang, rusak dan hancur dimakan usia.

Terdapat beberapa bangunan bilik padi yang utuh, tetapi sudah dialihfungsikan menjadi tempat penyimpanan peralatan pertanian dan lainnya. Seni ukir yang sebelumnya terdapat pada bilik padi juga tidak ditemukan adanya pengembangan atau 
penerapan pada media baru. Tidak dikembangkan kemudian akan hilang atau lenyap. Sebab tidak semua kebudayaan dapat bertahan, karena perkembangan teknologi yang semakin maju, akibatnya mendesak unsur-unsur tradisional, yang pada giliranya menimbulkan pergeseran nilai-nilai, arti dan fungsi dari suatu tradisi yang telah berkembang lama, lebih parahnya lagi dengan semakin berkembangnya teknologi tersebut dapat menghilangkan tradisi atau budaya lokal (Suwanto, dkk., 1999, 4).

Dilain pihak dikhawatirkan keberadaan dan kekayaan seni ukir Kerinci sebagai bagian dari pengetahuan tradisional dan ekspresi budaya tradisional akan hilang. Berdasarkan hal di atas dilakukan penelitian guna pemetaan dan pendokumentasian kekakayaan khasanah arsitektur dan elemen Bilik Padi tradisional Kerinci beserta seni ukirnya, agar tidak hilang serta dapat dikembangkan dikemudian hari.

Seni ukir pada Bilik Padi di Kerinci mempunyai peranan sangat penting bagi keberlangsungan pelestarian dan pengembangan nilai-nilai budaya. Guna mendata dan mendokumentasi arsitektur dan seni ukir pada bilik padi tradisional Kerinci sangat penting dilakukan penelitian secara mendalam. Berdasarkan pembahasan di atas, dan agar tercapai tujuan penelitian Bilik Padi Tradisional Kerinci, Arsitektur dan Seni Ukir ini, maka disusunlah rumusan masalah sebagai berikut; 1). Bagaimana struktur dan elemen bilik padi tradisional Kerinci, dan 2). Dimanakah diterapkan ornamen ukir pada Bilik Padi tradisional Kerinci.

Penelitian ini bertujuan untuk mendapatkan pemahaman yang lebih utuh keberadaan bilik padi tradisional Kerinci, arsitektur dan seni ukirnya di Kabupaten Kerinci dan Kota Sungai Penuh. Secara ekspilisit dapat dirumuskan tujuan sebagai berikut; 1). Menganalisis struktur dan elemen bilik padi tradisional Kerinci, dan 2). Mendata penempatan ukiran pada bilik padi tradisional Kerinci.

Penelitian dilakukan melalui metode penelitian kualitatif yang bersifat deskriptif analitik. Data yang terkumpul divalidasi, dianalisis selanjutnya disusun dalam bentuk deskriptif yang rinci, lengkap dan mendalam mengenai bagaimana struktur dan elemen bilik padi tradisional Kerinci, serta motif ukiran yang diterapkan. Strategi penelitian akan menggunakan metode observasi, dokumentasi dan interview.

Mengingat daerah Kerinci cukup luas, dan banyaknya komplek pemukiman tradisional yang terdapat bilik padi, maka ditetapkan lokasi penelitian wilayah Kerinci hulu; di Siulak. Wilayah Kerinci tengah; Kota Sungai Penuh. Wilayah Kerinci hilir; di Hiang dan Lolo Gedang. Dasar pemilihan lokasi tersebut karena daerah ini masih terdapat pola pemukiman tradisional dan bilik padi, yang diantaranya sudah berumur seabad lebih.

Informan penelitian ditentukan menggunakan teknik bola salju atau snowball sampling, yaitu teknik pengambilan sampel sumber data yang pada awalnya sedikit, lamalama menjadi besar. Hal ini dilakukan karena jumlah sumber data yang diperoleh sedikit, sehingga belum mampu memberikan data secara memuaskan. Perlu untuk mencari informan lain untuk dapat digunakan sebagai sumber data. Alasan memilih snowball sampling, karena melalui teknik ini peneliti akan mendapatkan banyak sumber informasi secara bergulir dari satu informan ke informan lainnya.

Berdasarkan permasalahan dan tujuan penelitian, dibutuhkan beberapa jenis-jenis data dalam penelitian ini, diantaranya data artefak, perilaku, dan dokumen. Jenis data ini akan diperoleh melalui sumbernya, yakni: (1) Objek bilik padi atau artefak. Melalui sumber 
ini nantinya akan diketahui struktur, konstruksi dan bagian-bagian bilik padi, termasuk ornamen ukirnya. (2) Perilaku, dalam hal ini dilihat melalui para pakar (ahli atau pembuat bilik padi), para pengamat (expert), dan pengguna (stakeholder), termasuk Depati, dan Ninik Mamak. Sumber ini dilihat mampu untuk memberikan informasi mengenai Konsep/pemikiran dan pemahaman serta perilaku masyarakat, serta pemaknaannya terhadap bilik padi. (3) Dokumen, dari sumber ini diharapkan diperoleh data mengenai arsiparsip, baik berupa tulisan maupun gambar atau foto tentang bilik padi, baik terkait visual bilik padi maupun konsep-konsep pemikiran terhadap bilik padi, maupun tata kehidupan masyarakat Kerinci secara tradisional dalam menggunakan bilik padi. (4) Kepustakaan, berupa buku-buku pendukung yang berhubungan dengan bilik padi. Sumbersumber data yang dijelaskan di atas, diharapkan mampu untuk menjawab permasalahan seni ukir bilik padi.

Teknik pengumpulan data dilakukan dengan observasi, wawancara dan dokumentasi. Penggunaan ke-tiga teknik tersebut diharapkan bisa saling melengkapi dalam memperoleh data yang diperlukan. Data divalidasi untuk diuji kemantapan, ketepatan dan kebenarannya dengan validitas menggunakan trianggulasi. Data dianalisis secara interaktif dan terus menerus, baik selama pengumpulan data maupun setelah dilakukan pengumpulan data. "Interaksi analisis tergambar dalam tiga alir utama, yaitu: reduksi data, penyajian data, dan penarikan kesimpulan" Hasil analisis akan disajikan melalui narasi analisis deskriptif. Hasil rangkuman interpretasi analisis dapat mengarahkan kepada kesimpulan.

\section{HASIL DAN PEMBAHASAN}

\section{a. Struktur dan Elemen Bangunan Bilik Padi Tradisional Kerinci}

Masyarakat Kerinci mendirikan rumah dan bangunan lainnya, termasuk bilik padi dilakukan sesuai ajaran para leluhur. Bentuk dan arsitektur bangunan menyesuaikan dengan kondisi lingkungan setempat. Bagi mereka hidup bukan di alam tetapi hidup bersama alam. Nilai-nilai tersebut merupakan nilai-nilai luhur yang perlu dipertahankan dan diaktualisasikan dalam kehidupan sehari-hari.

Masyarakat Kerinci tidak mengenal istilah lumbung padi, melainkan bilik padi. Dalam bahasa setempat disebut biloik yang artinya ruang atau kamar. Pemaknaannnya sama dengan bilik atau kamar di rumah tinggal. Hal ini disebabkan oleh tingginya penghargaan terhadap padi dalam masyarakat Kerinci. Padi tidak hanya dinilai sebagai hasil pertanian yang kemudian diolah menjadi beras dan dimasak menjadi nasi, untuk bahan makan pokok sehari. Melainkan sebagai sumber kehidupan, yang dalam kehidupan masyarakat tradisional cenderung di"sakralkan" dan dihormati sedemikian rupa, serta diperlakukan dengan tata aturan dan langkah tertentu. Mulai proses pengolahan lahan sawah, bertanam, merawat tumbuhan padi hingga panen dan menyimpannya. Salah satu penghargaan tersebut adalah dengan membuatkan "kamar" khusus untuk penyimpanan padi tersebut.

Bilik padi secara fisik berupa bangunan kayu yang dibuat khusus untuk penyimpanan padi dan hasil pertanian untuk pangan lainnya, seperti sorgum. Secara umum bentuk bilik padi tradisional Kerinci tidaklah memiliki ciri yang khusus, kekhasannya terlihat dari bentuk bangunannya yang membesar ke atas. Dinding dibuat miring, dalam istilah Kerinci dinamai sando Imang, pada beberapa bagian dinding dan tiang diterapkan ukiran. Arsitektur dan orientasi hadap bilik padi mengikuti rumah larik setangkup timur-barat atau menurut garis edar matahari, tetapi ada juga yang memanjang arah utara-selatan, rumah macam 
ini dinamakan larik malintang (Dinas Pariwisata dan Kebudayaan Kerinci, 2003, 54). Adanya larik malintang karena mengikuti arah aliran sungai yang juga mengalir arah utaraselatan.

Bangunan bilik padi tradisional Kerinci termasuk bangunan semi panggung, yang dibangun dengan menggunakan bahan yang berasal dari lingkungan setempat, berupa kayu dan bambu. Penggunaan bambu hanya untuk dinding yang disebut sasok, lantai yang disebut palupoah dan dudukan lantai; jeriau. Bilik padi dibangun di atas permukaan tanah dengan ketinggian satu hasta, di atas batu sendi atau umpak. Bilik padi tidak berjendela, seluruh dinding bangunan tertutup rapat. Pintu terdapat di sisi atas, di bawah bubungan atap.

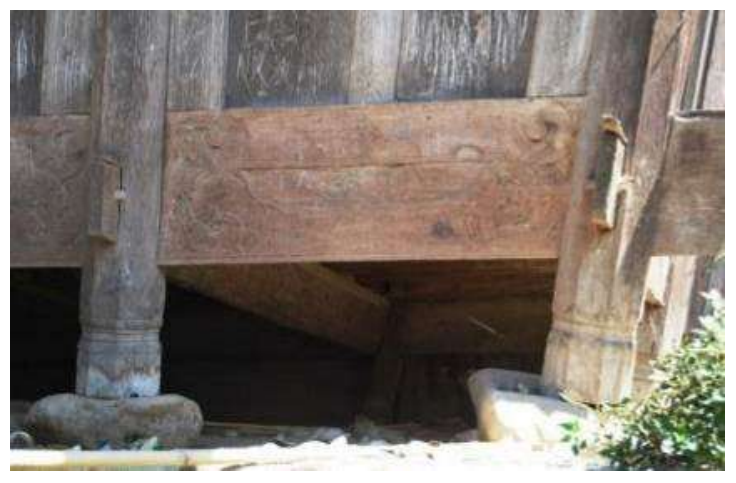

Gambar 1. Konstruksi Tapak Bilik Padi

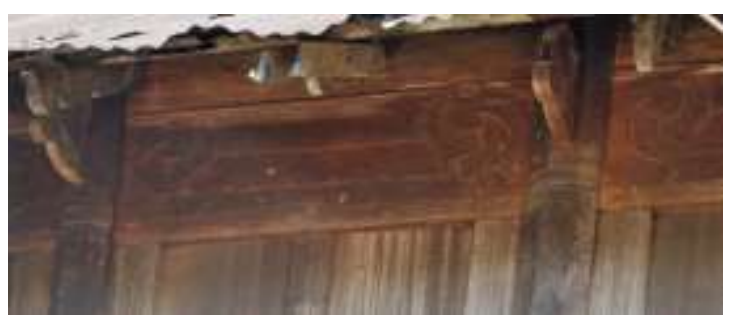

Gambar 2. Konstruksi Atas Bilik Padi

Bilik padi Kerinci dibangun dengan pengetahuan dan teknologi tradisonal yang memperlihatkan kesahajaan yang mengagumkan. Sebuah bentuk adabtasi sekaligus penyatuan terhadap alam. Konstruksi bangunannya tanpa menggunakan paku, hanya sistem pasak, atap lapis dari kayu atau kulit kayu, yang disebut atap sirap, tiang bersendi batu. Bilik padi dibangun di atas tiang dengan jarak yang rendah dari permukaan tanah. Secara fisik bilik padi berdenah persegi panjang, struktur bangunan terdiri dari satu lantai. Ukuran panjang bilik padi umumnya adalah empat sampai enam depa, lebar 2 depa, tinggi bubungan atap 4 depa, tinggi dinding samping 2 depa. Orang Kerinci mengukur jarak antara ruang-ruang dan elemen-elemen bangunan bilik padi dengan satuan ukuran (besaran) yang ada pada anggota tubuh manusia. Ukuran itu ialah ukuran tangan yaitu; depa; hasta; dan jengkal. 1 depa $=160-180 \mathrm{~cm}, 1$ hasta $=40-55 \mathrm{~cm}$ (Dinas Pariwisata dan Kebudayaan Kerinci, 2003, 113).

Konstruksi atap bilik padi dinamakan lipak pandang. Konstruksi lipat pandan diambil dari nama daun pandan (pandanus), tumbuhan yang dipakai untuk membuat anyaman. Daun pandan ini secara alami pada batangnya, akan patah 1/4 bahagian dari ujung, dan membentuk puncak segi tiga yang seimbang, seperti atap rumah larik. Ukuran lipat pandan di mana panjang tiang bubung lebih panjang dari pada lebar ruang depan atau belakang, panjang tiang bubung = 2 depa $+>1$ hasta. (Dinas Pariwisata dan Kebudayaan Kerinci, 2003, 108). Sama dengan bentuk bubungan rumah larik, ujung bubungan bilik padi lentik seperti biduk dan diberi puncak kayu berukiran, digambarkan pada pepatah adat berikut:

Atak lipak pandang lang manarak, bubung sawo mangampee (pepatah: Sungai Penuh). Ilok umah di palembahan, kasau malentuk bak palano, di tepi taletak balai, di pintu takenak jenjang, di tengah tapasang dama, babubung bakupang serak, batiang batang paseko, badinding balantak adat, malangkah ka bendun jati, puti duduk ateh mahligai, rajo duduk ateh kerajaan (pepatah: Siulak) 
(Dinas Pariwisata dan Kebudayaan Kerinci, 2003, 108).

Tiang pada bangunan bilik padi jumlahnya berbeda-beda, tergantung ukuran dari bilik padi tersebut. Bilik padi ukuran paling kecil dengan panjang tiga depa, tiangnya berjumlah sembilan buah, terdiri dari tiga baris; tiga buah tiang samping kanan, tiga buah tengah dan tiga buah samping kiri. Bilik padi ukuran paling besar dengan panjang empat depa, tiangnya berjumlah lima belas buah, lima buah tiang samping kanan, lima buah tengah dan lima buah samping kiri. Selain tiang utama biasanya ditambah tiang plasa (balkon) satu buah, tetapi tidak semua plasa bilik padi diberi tiang, ada yang plasa-nya menempel lansung ke konstruksi utama dan tiang tengah.

Pada umumnya tiang bilik padi dibentuk persegi delapan, dengan diameter ukuran satu hingga satu setengah jengkal orang dewasa (25 cm sampai $30 \mathrm{~cm}$ ) tergantung pada besar dan kecil serta tinggi bangunan. Bentuk tiang segi delapan, yang mengandung makna delapan penjuru (tujuh tingkat salapan penjuru), bersumber dari hukum adat yang disebut dengan undangundang pucuk larangan ngan salapan, negeri yang empat adat yang empat (Dinas Pariwisata dan Kebudayaan Kerinci, 2003, 108).

Pemasangan tiang memperhatikan bagian pangkal dan ujung kayu, bagian pangkal kayu harus berada di sebelah bawah di atas sendi batu, dan bahagian ujung kayu harus berada di bagian atas. Balok rasuk dan kayu lainnya dipasang dalam posisi horizontal, tidak menjadi masalah kemana arah pangkal atau ujung kayu. Guna mengetahui di mana letak pangkal dan ujung tiang, dilakukan dengan cara menimbang tiang itu pada sebuah ganjal batu. Dengan cara ini dapat diketahui, mana yang berat inilah pangkal kayu dari jarak titik tengah tiang (Dinas Pariwisata dan Kebudayaan Kerinci, 2003, 114-115).

Dinding bilik padi dipasang menutupi keempat sisi bangunan. Pada umumnya dinding terbuat dari papan, dipasang dalam bentuk lembaran panil. Posisi dinding menempel pada tiang dan mengembang ke atas, diapit oleh bingkai-bingkai panil yang melekat lansung pada tiang dan balok bawah dan atas. Dinding miring (sando Imang) kemiringannya sama dengan letak bambu untuk lemang di unggun perapian. Cara pasang dinding miring ini cukup rumit, disamping menggunakan pasak-pasak dan kayu penahan dinding, juga dinding dalam posisi dapat pegangan dari balok kasau.

Pembuatan dinding bilik padi miring, atau mengembang ke atas untuk tujuan mempersulit hama tikut naik ke atas, dan masuk bilik padi melalui bawah atap. Bagian ini yang rentan menjadi tempat masuk tikus, karena terdapat celah-celah antara ujung papan dinding dengan atap. Bagian bawah tidak ada celah untuk tikus masuk, selain bisa dibuat rapat juga kayunya keras. Sementara konstruksi atap yang terdapat bagian tinggi rendah, maka menyebabkan ada celah.

Lantai bilik juga dibuat dari papan kayu, tetapi ada juga yang terbuat dari palupouh (bambu). Di bawah lantai ada jeriau, terbuat dari bambu bulat, penahan lantai. Di bawah jeriau ada gelegau atau gelegar yang terbuat dari balok kayu, yang terhubung ke tiang-tiang berfungsi menahan jeriau dan lantai. Posisi pintu bilik tinggi, ditempatkan di bawah bubungan atap bagian depan, atau bagian pangkal bangunan. Pintu berukuran kecil, lebar satu hasta dan tinggi satu depa, sehingga untuk keluar masuk harus merunduk. Bukaan daun pintu ke luar. Guna memasukkan dan mengeluarkan padi dari bilik menggunakan tangga. Terdapat dua tangga pada satu bilik padi, tangga di luar bangunan dan tangga di dalam bangunan. 
Tempat menyandarkan tangga luar dibuatkan balkon, posisi tangga menyamping dalam bahasa kerinci disebut plasa. Plasa ada yang ditopang tiang khusus, ada juga yang tanpa tiang dan dirangkai lansung dengan konstruksi utama bangunan bilik dan tiang tengah. Pada beberapa bilik padi ada tangga yang dipasang secara permanen, karena padinya digunakan untuk keperluan seharihari. Ada pula tangga yang bisa dibongkar pasang, terutama pada bilik yang padinya untuk keperluan atau hajatan tertentu. Tangga dalam dipasang permanen, digunakan untuk menempatkan atau mengambil padi yang disimpan di lantai. Padi yang disimpan di dalam bilik adalah padi yang masih bertangkai, dengan proses panen menggunakan sistim tuai, sehingga untuk menyimpan dan mengeluarkannya tidak terlalu sulit. Kumpulan tangkai-tangkai padi sudah disusun dan diikat sedemikian rupa.

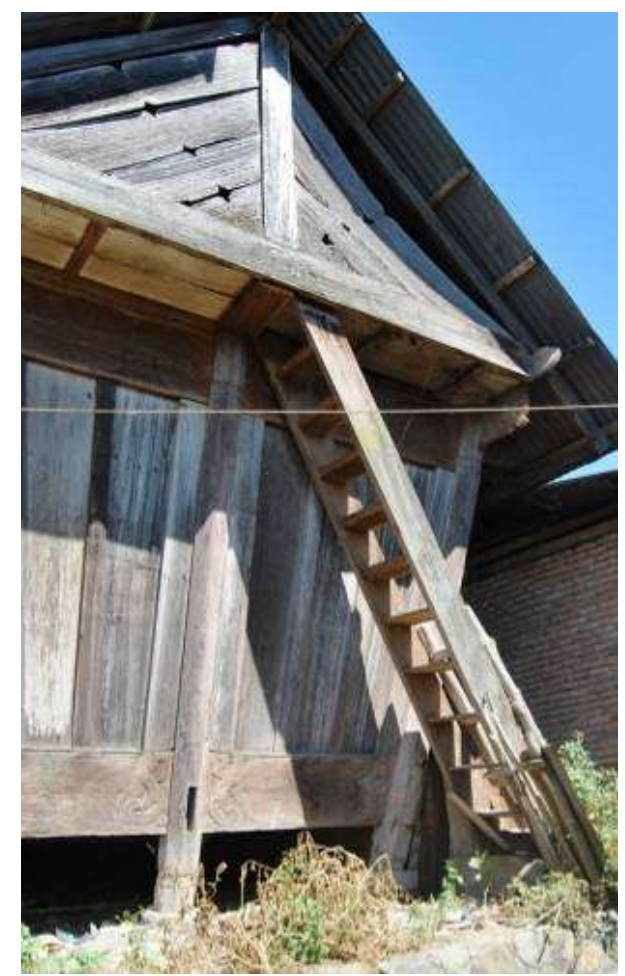

Gambar 3. Model Tangga Bilik Padi Menyamping tanpa Tiang

Bentuk Tanggo bilik padi ada dua macam yaitu: a) Tanggo Jantan (tangga tunggal), adalah sebatang kayu yang telah ditakik sedemikian rupa untuk pijakan kaki dengan bentuk yang sama.; b) Tanggo Batino, merupakan tangga yaang terbuat dari papan tebal dengan takah-takah atau anak tangga. Kedua anak tangga tersebut dihitung dengan hitungan kata-kata, 1) takik, 2) tinggah, 3) tunggu, 4) tingkah, 5) takih, 6) tanggo, dan 7) tunggu. Anak tangga atau takikan selalu berjumlah ganjil; 5, 7 dan 9, sesuai dengan tinggi bangunan bilik padi.

Bilik padi secara umum hanya terdiri dari satu ruang saja, tetapi dalam penggunaannya dibuat sekat-sekat yang tidak permanen. Sehingga sewaktu-waktu dapat dibuka dan dipasang kembali sesuai kebutuhan. Sekat tersebut dibuat untuk memisahkan antara padi yang baru dipanen dengan yang telah lama disimpan, atau untuk memisahkan antara satu jenis padi dengan jenis yang lain. Selain itu juga untuk memisahkan padi peruntukan tertentu, seperti untuk dikonsumsi sehari-hari dengan untuk benih, untuk hajatan tertentu dan sebagainya.

Tiang bilik padi didirikan di atas batu pondasi (umpak) yang disebut batu sendai. Hal ini dimaksudkan agar tiang tidak terbenam ke dalam tanah serta menjaga pangkal tiang agar tidak bersentuhan lansung dengan tanah sehingga mempermudah proses pelapukan, serta dalam kepercayaan lama pada masyarakat, batu dianggap mempunyai kekuatan spritual. Secara konstruksi juga mereduksi goncangan ketika terjadi gempa. Batu pondasi yang dipilih harus dua permukaannya rata, yang permukaannya paling baik mengarah kepada tiang. Batu pondasi diletakkan di atas tiga buah batu yang berfungsi sebagai batu alas. Batu bantalan ini dinamai tungku tigo, batu ini lebih kecil dari batu fondasi, yang berguna untuk gaya main bangunan rumah sekiranya ada gempa; untuk menyetel ketinggian dari tiang-tiang, agar memiliki kerataan waterpass dengan cara 
sistem pengungkit (Dinas Pariwisata dan Kebudayaan Kerinci, 2003, 115).

Konstruksi bilik padi dibuat dengan teknik yang sedemikian rupa menggunakan pasak. Sekarang terlihat adanya penggunaan paku besi, maka itu adalah penambahan diwaktu kemudian dalam usaha untuk memperkokoh bagian-bagian bilik padi yang sudah rusak atau lapuk. Hampir keseluruhan bangunan bilik padi yang dijadikan sampel konstruksinya sudah diperkuat dengan paku, karena pasak dan kunci-kunci sudah banyak yang rapuh, terutama pada kerangka dinding luar. Pada kerangka pintu dan tangga banyak yang sudah ditambahkan bingkai dan les untuk memperkuat kedudukan dinding.

\section{b. Penciptaan Motif Ukiran Bilik Padi Kerinci}

Motif hias yang digunakan pada bilik padi sama dengan motif yang diterapkan pada rumah larik, mempunyai akar sejarah yang panjang, karena terdapat beberapa buah motif ukirannya yang berasal dari motif hias masa prasejarah. Motif hias tersebut telah mengalami pengembangan bentuk, pada setiap periodenya, seperti motif stilir matahari, dan motif bentuk binatang.

Seni ukir sebagai bagian dari seni rupa, khususnya yang terdapat di daerah Kerinci ditenggarai sudah ada sejak lama, sudah dimulai sejak zaman prasejarah, 500-980 SM (Wiyoso, 1981/1982, 2, dan Ja'far, 1998/1999, 9). Meskipun penamaan artefak dari karya seni tersebut tidak sama dengan apa yang dipahami dengan seni ukir pada masa sekarang. Karena, masih berupa pahatan atau gambar tertentu, yang medianya paling banyak adalah batu, seperti benda-benda mikrolit berupa kapak dan lainnya yang bentuk dan corak garis, lengkungannya sangat indah. Benda-benda ini ditemukan di sekitar danau Kerinci (Wiyoso, 1981/1982, 2). Selain itu terdapat bangunan batu atau menhir, bejana perunggu, pecahan tembikar yang sudah dihiasi dengan motif-motif. Pahatan-pahatan pada bangunan batu, maupun benda lain inilah yang diperkirakan sebagai dasar pembentukan ukiran pada rumah larik, bilik padi dan Masjid kuno di Kerinci, terutama untuk bentuk-bentuk motif tertentu.

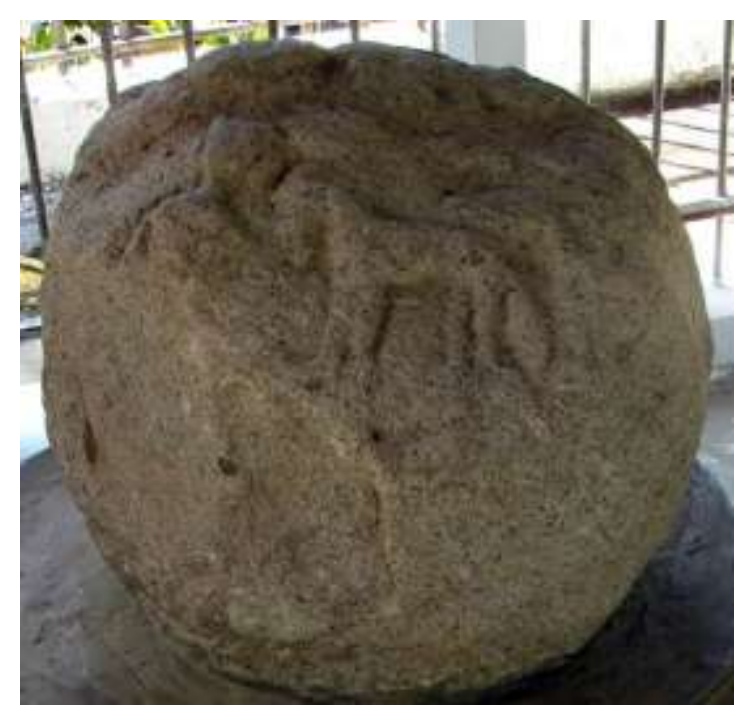

Gambar 4. Batu Bergambar, di Desa Muak, Kerinci

Setelah berakhirnya zaman batu, penerapan motif hias di Kerinci terus berkembang. Seperti yang dijelaskan Holt, bahwasanya: seni yang berkembang pada masa Neolitik, tidak lenyap dengan hadirnya masa Perunggu, dan bahkan keduanya juga tidak hilang pada masa kemudian (Holt, 2000, xix). Jika sebelumnya bangunan batu yang dihias, periode berikutnya pada benda-benda untuk berbagai peralatan kehidupan praktis mereka yang dihias, seperti pada bejana perunggu. Bejana perunggu ini ditemukan di sekitaran Danau Kerinci. Selain bejana perunggu juga ditemukan gerabah, serta benda-benda perhiasan tubuh, seperti manikmanik. 


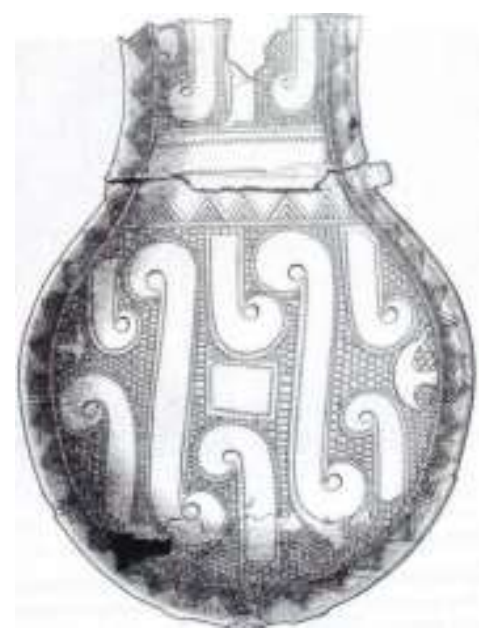

Gambar 5. Bejana Perunggu Kerinci

(A. J. Bernet Kempers, dalam Soedarso SP, 2006, 62)

Mengikuti pendapat Holt tersebut memang sangat dimungkinkan seni yang telah berkembang pada masa-masa awal terus berlanjut, dan semakin berkembang pada masa berikutnya. Setelah masuknya Islam ke Kerinci, juga tidak sepenuhnya menghapus seni-seni yang telah berkembang sebelumnya. Terkait motif hias dan bangunan batu dijelaskan Alimin, (wawancara, Alimin, 27 Maret 2019) pahatan motif-motif spiral atau lingkaran pada batu tersebut merupakan penggambaran dari matahari. Pada umumnya bangunan batu tersebut menghadap ke arah matahari terbit. Sebetulnya pada bilik padi maupun rumah larik tidak ditemui bentuk ukiran persis sama dengan yang terdapat pada tinggalan bangunan batu tersebut. Pada batu silendrik terdapat pahatan motif berbentuk lingkaran berganda yang semakin ke tengah atau ke dalam semakin mengecil lingkarannya. Pada bilik padi juga terdapat motif berbentuk lingkaran, yang dinamakan simatoahai, sardu matoahai dan bungea matoahai.

Motif sulur-suluran yang diterapkan pada bangunan bilik padi apabila dibandingkan dengan motif pada batu silendrik memang tidak sama tetapi sama-sama mempunyai bentuk dasar sulur-suluran tumbuhan. Motif seperti ini ditemukan pada bilik padi. Motif pilin-pilin dikenal dengan motif lampit simpae, lung kangkung patah tumbuh hilang beganti, dan lainnya, motif tumpal dikenal dengan motif pucuk rebung.

Tinggalan masa prasejarah tersebut menjadi akar sejarah dari seni ukir di Kerinci, termasuk yang diterapkan pada bilik padi, karena kebudayaan Neolitikum dan Perunggu adalah dasar dari kebudayaan Indonesia (Hoop, 1949: 4, Gustami, 2008, 27). Motif yang tidak ada pada bilik padi hanya bentuk dari perwujudan mahkluk hidup.

Motif ukiran di Kerinci selain berasal dari motif hias yang telah berkembang pada masa prasejarah, juga berasal dari pengaruh motif ukiran yang berkembang di daerah sekitar, terutama dari daerah Minangkabau. Kemudian juga pengaruh dari motif hias Islam, seperti motif choznat bil hamz yang berasal dari Arab, dilengkapai dengan motif turiq (daun). Diperkuat oleh pendapat Zakaria (1984b: 70) bahwa, motif hias dan seni ukir di Kerinci lebih banyak berkembang setelah masuk dan berkembangnya Islam di Kerinci. Sehingga seni ukir di Kerinci paling banyak ditemui pada bangunan Masjid, karena masyarakat membuatnya secara total, direncanakan dan dibuat tidak hanya oleh satu keluarga tetapi terdiri dari banyak kaum dalam suatu dusun, sehingga hasil ukirannya menjadi maksimal.

Penciptaan motif hias dan seni ukir semakin pesat setelah masuknya Islam, karena yang ditumpangkan di dalam ukiran tersebut tidak hanya nilai-nilai adat tetapi juga nilai-nilai ajaran Islam dan penyatuannya dengan nilai adat yang sudah ada pada masa sebelumnya. Di samping itu faktor terpenting yang mendorong semakin berkembangnya penciptaan motif hias dan penggunaan ukiran juga adanya dukungan dan peran pemuka adat, dengan berbagai makna dan nilai yang ditumpangkan ke dalam ukiran tersebut. Pada tahap ini penciptaan seni ukir pada bilik padi tidaklah berhenti pada ukiran, akan tetapi seni ukir tersebut selain berperan sebagai hiasan 
juga mengusung maksud dan simbol tertentu. Salah satunya terkait para pemegang kebijakan di dalam kaum dan dusun, yang selama ini ikut menyokong keberadaan ukiran tersebut.

Pemuka adat masyarakat Kerinci, yang disebut Uhang Empat Jenis (Depati dan Ninik Mamak, Alim Ulama dan Cerdik Pandai, Tengganai dan Hulu Balang), merupakan suatu lembaga yang sangat berperan dalam penciptaan dan pembuatan ukiran di Kerinci, dengan menjadikan motif ukiran tersebut sebagai sarana legitimasi kedudukan dan fungsi keberadaan mereka. Motif Glang-glang atau motif Tigo Takah misalnya yang terdapat pada bilik padi, rumah larik dan Masjid dijadikan simbol dari kehadiran Depati, Ninik Mamak, dan Tengganai dalam suatu kaum.

Selain untuk menyimbolkan berbagai fungsi dan kedudukan dari pemuka adat tersebut, di dalam ukiran tersebut juga turut dimuat unsur dan norma-norma adat yang lain, baik yang bersifat konsepsi maupun teknis pelaksanaan hukum adat. Tiang bilik padi yang dibuat segi delapan misalnya, adalah untuk melambangkan sistem hukum adat yang delapan. Delapan buah hukum kriminal dan delapan buah hukum perdata. Termasuk pembuatan bagian atau elemen-elemen tertentu pada bilik padi harus memenuhi kaidah atau ukiran tertentu, tujuannya tidak lain untuk menambah nilai dan makna dari bilik padi bersatu dengan segala hal yang terkait dengannya.

Dalam penciptaan ukiran tersebut, masyarakat Kerinci menamakan masingmasing jenis ragam hias atau motif ukirannya berdasarkan kemiripannya dengan dunia empiri. Nama-nama motif hias tersebut diiambil dari nama tumbuh-tumbuhan, binatang dan alam benda, misalnya, motif hias Bungea Kemboja (bunga kamboja), Simatoahai (matahari), Ula Gerang (Ular), dan lain-lain. Kondisi yang demikian merupakan bukti sekaligus cerminan kedekatan dan pemahaman orang Kerinci terhadap alam. Visualisasi motif tidaklah kongkrit seperti wujud asli benda atau mahkluk hidup yang diacu, tetapi telah distilir. Hal ini memberikan pemahaman akan tingginya rasa estetika dan penguasaan teknik oleh masyarakat Kerinci pada masa tersebut.

\section{c. Ukiran Bilik Padi Tradisional Kerinci}

Seni merupakan kebutuhan bagi manusia, guna menuju kesempurnaan hidup. Berbagai usaha dilakukan untuk memenuhi kebutuhan tersebut, mulai dari memperindah atau merias diri/tubuh, benda-benda dan peralatan hidup sehari-hari, sampai kepada bangunan tempat tinggal dan lingkungan sekitar. Sejarah membuktikan kebutuhan akan nilai-nilai keindahan tidak hanya muncul pada masyarakat modern, yang pola dan penghidupannya telah mapan, tetapi juga dalam masyarakat tradisional bahkan masyarakat primitif sekalipun. Seni dalam masyarakat tradisional muncul tentu berbeda latar belakang dan tujuannya dengan seni dalam masyarakat modern, terkadang juga kehadiran seni tersebut bukanlah untuk tujuan keindahan, tetapi untuk tujuan religi dan upacara-upacara adat. Demikian juga perwujudannya terkadang juga tidak indah bila diukur dengan konsep-konsep seni modern sekarang ini.

Masyarakat tradisional Kerinci pada masa lalu juga telah berkecimpung dengan seni, di antaranya dengan menghias bilik padi dan bangunan lainnya, dengan berbagai motif ukiran. Seni ukir pada bilik padi tersebut merupakan salah satu bentuk seni tradisi masyarakat Kerinci. Berkembang dari keinginan masyarakat untuk memberikan "tanda" bentuk dari penghargaan dan penghormatan terhadap keberadaan bangunan bilik padi tersebut. Ukiran dibuat dalam bentuk yang sederhana, sebagaimana yang masih dapat disaksikan sampai saat ini, 
dan hanya ditempatkan pada bagian tertentu saja, tidaklah memenuhi seluruh elemen bangunan.

Berdasarkan hasil pengamatan di lapangan diketahui bahwa bagian dari bangunan bilik padi yang dihias ukiran adalah; tiang, balok atas dan bawah, dinding, pintu, alang, dan kasau. Menurut narasumber, selain pada bagian-bagian tersebut sebetulnya ukiran juga ada yang diterapkan pada tangga, plasa (teras), serta elemen lainnya. Tetapi bagianbagian tersebut pada umumnya sudah rapuh kemudian diganti dengan yang baru, sehingga bentuk yang asli sudah tidak ditemukan lagi.

Bilik padi yang menjadi sampel dalam penelitian ini terdiri 3 buah, diambil dari wilayah Kerinci mudeek/hulu, tngoh/tengah dan ilee/hilir. Sebaran sampel tidak dipilih berdasarkan pembagian wilayah kecamatan atau desa yang ada sekarang, karena kecamatan dan desa sekarang tidak dapat sepenuhnya mewakili wilayah pemukiman lama masyarakat Kerinci pada masa dahulu.

Penamaan Kerinci Hulu, Tengah maupun Hilir, berdasarkan kebiasaan umum masyarakat Kerinci, untuk menyebut daerahdaerah tertentu berdasarkan posisinya dengan arah aliran sungai. Daerah yang berada di bagian hulu sungai Batang Merao disebut masyarakat dalam bahasa setempat mudeek;/mudik atau hulu, serta yang daerah yang berada di pertengahan aliran Batang Merao sampai sekitaran muaranya di Danau Kerinci di sebut tngah; tengah, dan untuk daerah yang berada di muara Danau Kerinci, dan sepanjang atau daerah yang searah aliran Batang Merangin dinamakan ilee; hilir. Berdasarkan hal tersebut pembagian wilayah untuk pengambilan sampel penelitian ini. Daerah tersebut meskipun berada dalam satu payung kebudayaan Kerinci, tetapi adat samo, ico pake babidei. Adat sama, tetapi memiliki karateristik sendiri-sendiri dalam pemakaiannya, baik persolan bahasa (dialek), gelar-gelar adat, sampai kepada seni ukirnya.

Pemilihan sampel didasarkan atas pertimbangan untuk mewakili ketiga pembagian wilayah tersebut. Ketiga sampel tersebut memang belum sepenuhnya dapat mewakili ketiga daerah tersebut, apalagi periode perkembangannya, hal ini disebabkan tidak setiap dusun atau daerah masih memiliki bangunan bilik padi, meskipun dahulunya merupakan pemukiman tua (latih). Ketiadaan bangunan bilik padi pada daerah-daerah tersebut disebabkan karena bangunannya sudah dibongkar, terbakar, atau roboh karena dimakan usia, maupun sebab lainnya. Sampel penelitian diantaranya.

\section{Bilik Padi Dusun Baru, Siulak}

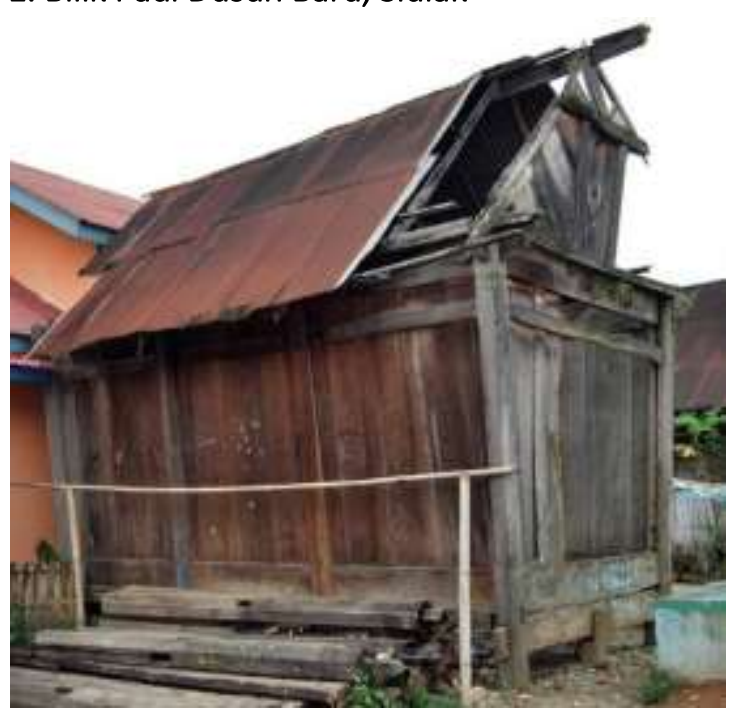

Gambar 6. Bilik Padi di Siulak

Bilik padi ini berada di dusun Baru Siulak, sudah lama tidak digunakan, kondisi bangunan sudah rusak di setiap bagian; lantai, atap dan dinding. Panjang bangunan 3 depa dan lebar 2 depa. Dari bilik padi yang pernah ada di larik ini merupakan satu-satunya yang tersisa. Atap sirap sudah diganti dengan atap seng. Bilik padi yang lain telah dibongkar bersamaan pembongkaran rumah larik yang ada di komplek tersebut, terlihat di samping bilik padi terdapat sejumlah tiang rumah larik. 
Menurut Kamarudin (wawancara, Wahid, 26 Maret 2019), bahwa posisinya dahulu di tengah, diapit oleh petak rumah larik yang lain. Bilik padi ini terletak di bagian belakang dari parit ngan basudut empat.

Menurut Kamarudin dan Wahid, bahan utama pembuatan bilik padi ini sama dengan bahan untuk pembuatan rumah larik yang ada di komplek tersebut, yakni kayu Medang Jangkat, terutama untuk tiang, alang, usuk, dinding, dan bagian lainnya. Dusun Baru Siulak menurut Wahid, termasuk salah satu pemukiman tua yang terdapat di bagian mudeek atau Kerinci hulu (wawancara, Wahid, 26 Maret 2019). Dalam pepatah adat, disebutkan mudeek sulak ilee tamiai, sulak malentuk mudek, tamiai malentuk ilee, sarengkuh dayuang, salatuah bdei, sebagai batas teritorial adat dan persatuan Kerinci Tinggi pada masa dahulu. Siulak juga merupakan ujung rantau sekaligus kepala rantau. Ujung rantau dari daerah Minangkabau dan kepala rantau dari Melayu Jambi. Daerah titik temu antara dua budaya Minangkabau dan Melayu Jambi.

Bilik padi ini minim ukirannya, terdapat pada tiang bagian atas dengan motif geometris Paku Rancah, Kukea Gajeah, Bungea Kemboja, dan Pahuh Enggang. Ukiran pada pengapit dinding atas dengan motif Pahuh Enggang, pada balok atas dengan motif Keluk Paku, serta pada pengapit dinding bawah dengan motif Luk Paku Kacang Belimbing. Motif ini terdiri dari banyak varian, demikian pula motif pendukungnya. Meskipun demikian tetap mempunyai bentuk dasar segi tiga (tanaman pakis yang dipancung). Motif Paku Rancah diukir mengelilingi tiang bilik bagian atas lebih kurang 20-25 cm sebanyak lima baris; dua baris di atas, dua baris di bawah, dan satu baris yang di tengah-tengah. Motif dipahat dalam ukuran yang kecil-kecil. Sebagian ukiran ada yang diwarnai, sebahagian sudah hanya kondisi kayu yang sudah menghitam karena faktor usia. Penempatan motif disertai dengan motif Glang-glang atau motif tigo takah dua baris yang dibatasi motif paku rancah, juga dalam ukuran yang kecil. Ukiran pada bilik padi ini sebahagian masih terlihat sisa warna, yakni warna merah, putih, hijau dan hitam. Selain ukiran, tidak ada jejak bangunan ini pernah diwarnai.

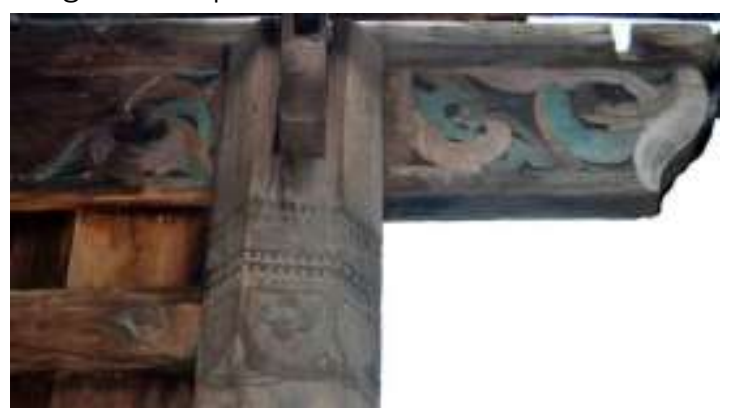

Gambar 7. Ukiran Ukiran motif Lung Kangkung Patah Tumbuh Hilang Baganti haluan Balok atas dan ukiran motif Paku Rancah, Kukea Gajeah, Bungea Kemboja, Tigo Takah, Glang-glang dan Pahuh Enggang pada Tiang bagian atas

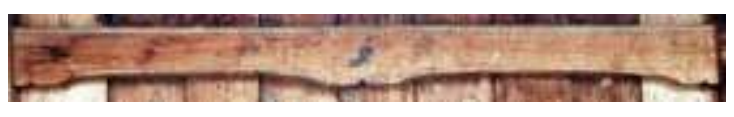

Gambar 8. Ukiran profil pengapit dinding

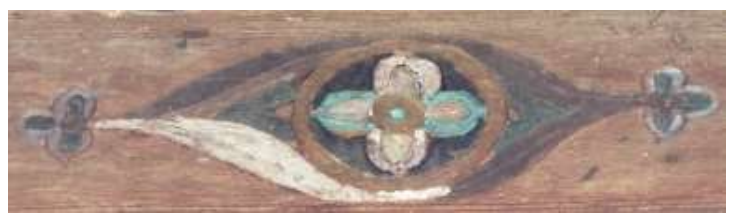

Gambar 9. Ukiran Bungea Kemboja pada bagian tengah pengapit dinding

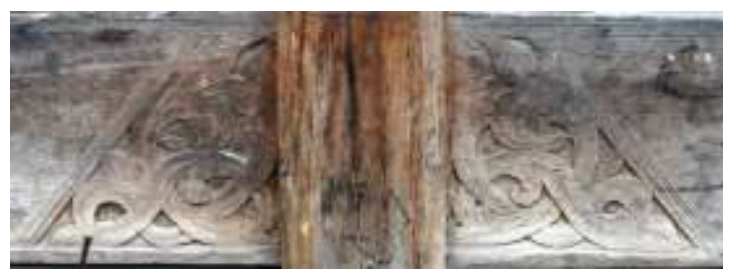

Gambar 10. Ukiran Ukiran motif Lung Kangkung Patah Tumbuh Hilang Baganti pada Balok Bawah

\section{Bilik Padi Sungai Penuh}




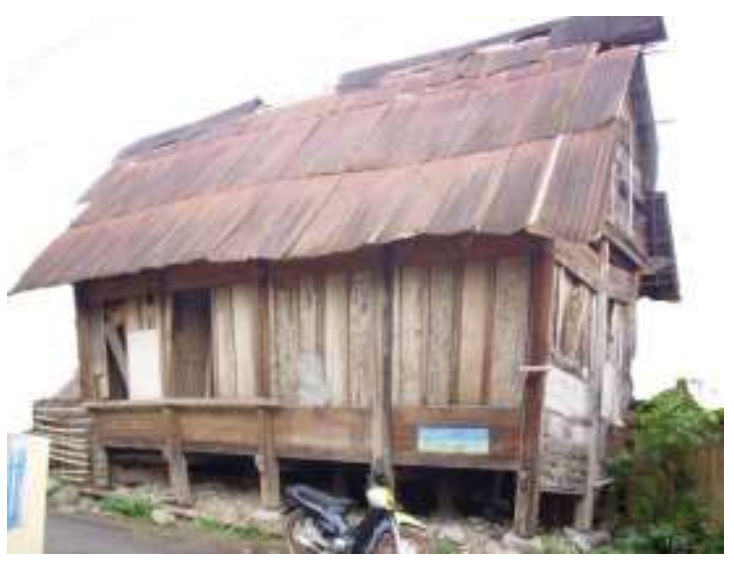

Gambar 11. Bilik Padi di Sungai Penuh

Bilik padi ini berada di dusun Baru Sungai Penuh, sudah lama tidak digunakan, kondisi bangunan sudah rusak di setiap bagian; lantai, atap dan dinding. Panjang bangunan 4 depa dan lebar 2 depa. Dari bilik padi yang pernah ada di larik ini merupakan satu-satunya yang tersisa. Atap sirap sudah diganti dengan atap seng. Bilik padi yang lain telah dibongkar bersamaan pembongkaran rumah larik yang ada di komplek tersebut. Pada dinding dan ukiran tidak ada bekas pernah diwarnai.

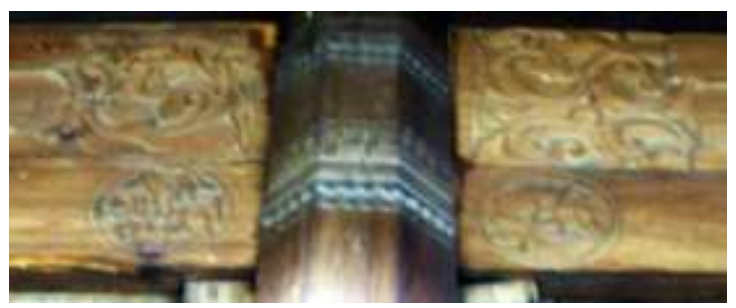

Gambar 11. Ukiran pada Keluk Paku Balok Atas, dan ukiran Paku rancah, Kuku Gajeah dan Tigo Takah pada Tiang

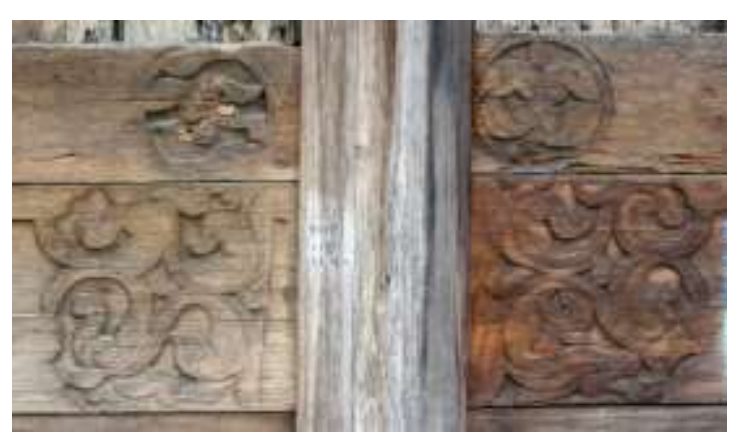

Gambar 12. Ukiran Keluk Paku pada Balok Bawah

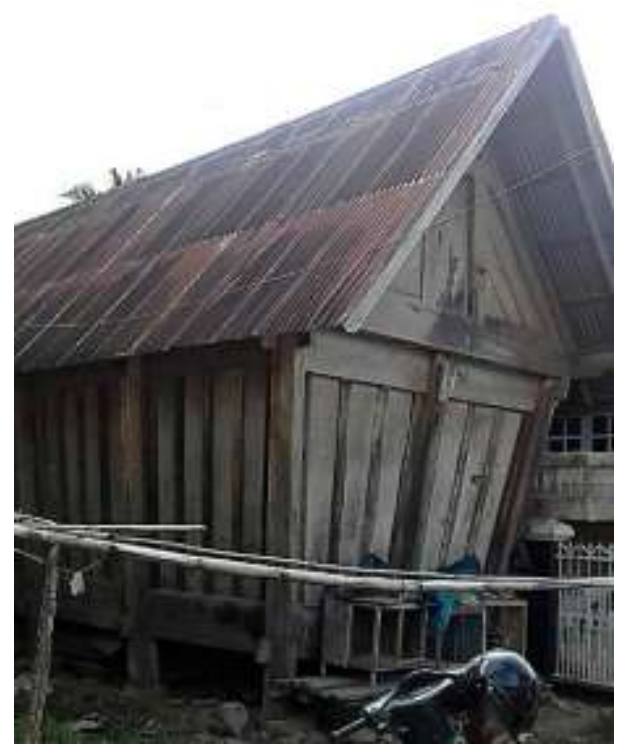

Gambar 13. Bilik Padi di Pendung Hiang

Bilik padi ini berada di Larik Panjang Pendung Hiang. Panjang bangunan 3 depa dan lebar 2 depa. Bilik padi menghadap ke utara membujur timur-barat. Bilik padi ini juga sudah lama tidak digunakan, kondisi bangunan secara umum masih utuh. Hanya atap sirap sudah diganti dengan atap seng. Pada bilik padi ini hampir tidak ada ukiran, hanya bagian atas konsen pintu dibuat kerawangan. Bangunan bilik padi ini tidak pernah diwarnai.

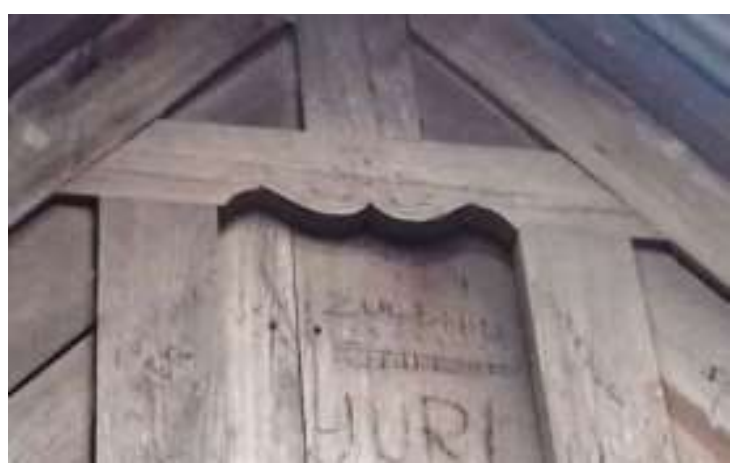

Gambar 14. Kerawangan konsen pintu bilik padi

\section{Bilik Padi Lolo Gedang}

\section{Bilik Padi Pendung Hiang}




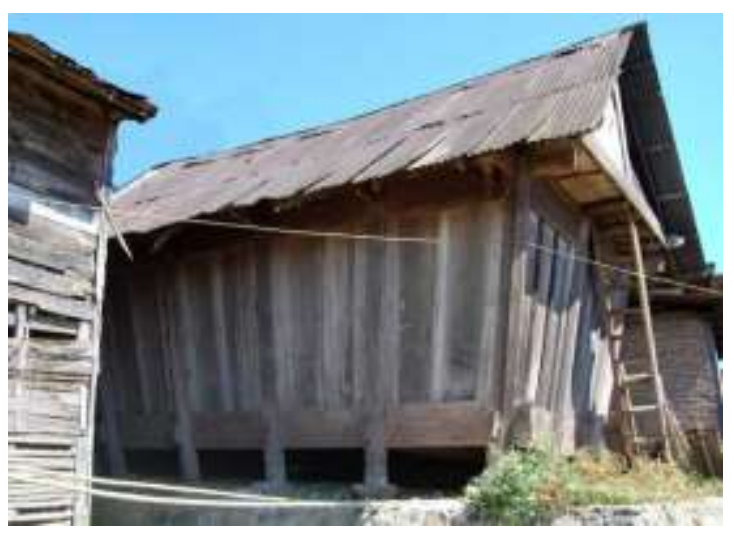

Gambar 15. Bilik Padi di Lolo Gedang

Bilik padi ini berada di Desa Lolo Gedang. Panjang bangunan 4 depa dan lebar 2 depa. Bilik padi menghadap ke utara membujur timur-barat. Bilik padi ini juga sudah lama tidak digunakan, kondisi bangunan secara umum masih utuh. Hanya atap sirap sudah diganti dengan atap seng. Ukiran pada bilik padi ini cukup banyak, terdapat pada tiang bagian atas dengan motif geometris Paku Rancah, Kukea Gajeah, Gungea Kemboja, dan Pahuh Enggang. Ukiran pada pengapit dinding atas dengan motif Pahuh Enggang, pada balok atas dengan motif Keluk Paku, serta pada pengapit dinding bawah dengan motif Luk Paku Kacang Belimbing. Pada bangunan tidak ada jejak pernah diwarnai, hanya bagian ukiran atas samar-samar masih terlihat sisa pewranaan ukiran, yakni warna merah, kuning, hijau dan hitam.

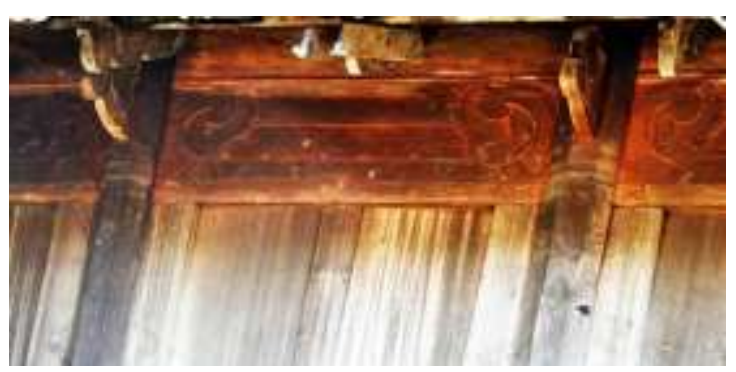

Gambar 16. Ukiran Ukiran motif Ula Gerang haluan Balok atas dan ukiran motif Paku Rancah, Kukea Gajeah, Bungea Kemboja, Tigo Takah dan Pahuh Enggang pada Tiang Atas

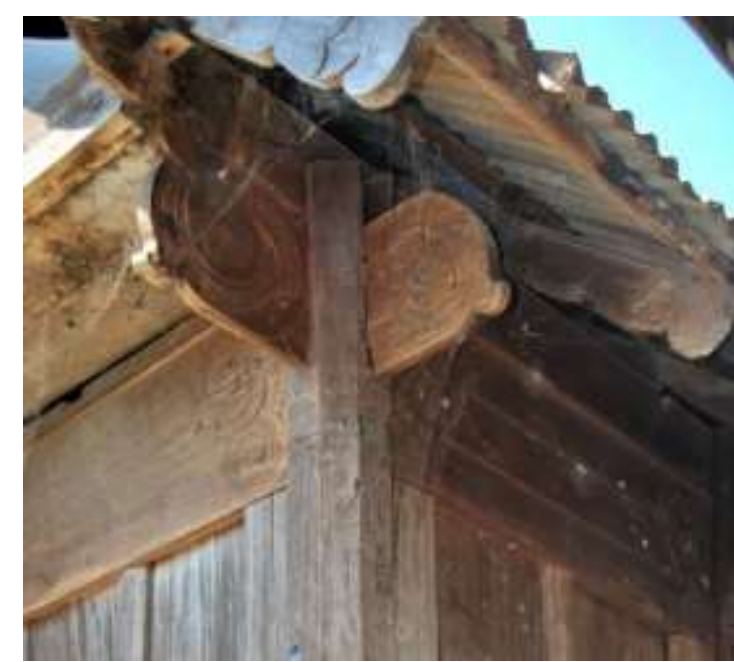

Gambar 17. Ukiran Ula Gerang pada ujung balok atas tiang

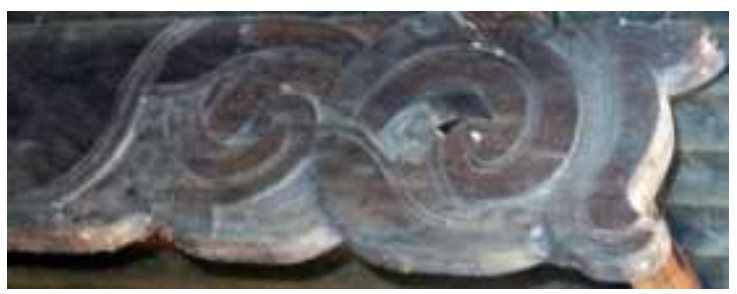

Gambar 18. Ukiran motif Gadeig-gadeig pada ujung kasau

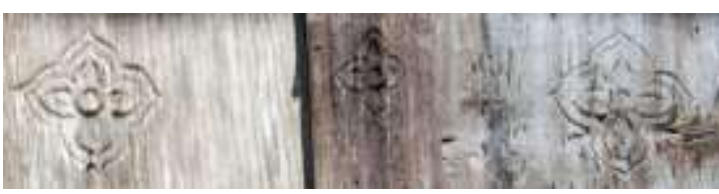

Gambar 19. Ukiran Bungea Kemboja pada Dinding

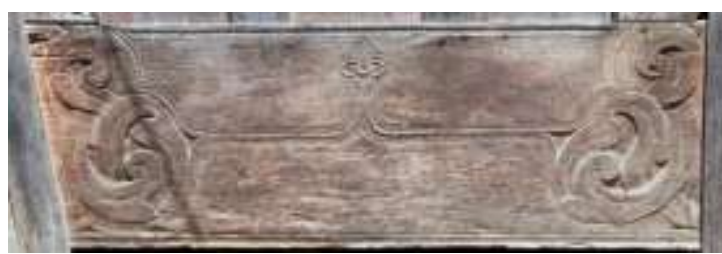

Gambar 20. Ukiran Ukiran motif Lung Kangkung Patah Tumbuh Hilang Baganti Pada Balok Bawah

Berdasarkan temuan di lapangan, dari keempat bilik padi yang menjadi sampel penelitian yang ukirannya paling baik adalah bilik padi di Siulak dan Lolo Gedang. Ukirannya cukup bervariatif, teknik penggarapannya cukup halus, pewarnaannya juga baik, termasuk pemilihan letak masing-masing motif sangat ideal. Berdasarkan kondisi yang ada 
saat ini, barangkali dahulunya setiap bilik padi tersebut ukirannya juga bagus. Tetapi karena rata-rata usia bangunan tersebut sudah cukup tua, dalam hitungan puluhan bahkan ada yang diatas seratus tahun. Kondisinya sebagian sudah rusak, kayunya sudah banyak yang keropos dan dimakan rayap. Apalagi dinding sebelah luar sering kena percikan air hujan dan sinar matahari lansung, semakin mempercepat proses pelapukan. Selain itu juga karena bilik padi sudah tidak difungsikan lagi, perawatan yang juga hampir tidak ada semakin mempercepat rusaknya ukiran dan bangunan tersebut.

Nama motif ukiran menurut narasumber diberikan oleh generasi yang melanjutkan penggunaan dan pengembangan motif tersebut (wawancara, Rahimna, 8 Maret 2019). Generasi pertama hanya menvisualisasikan ide-ide mereka kebentukbentuk ukiran. Pemberian nama tersebut berdasarkan cerita-cerita yang mereka terima dari genersi pendahulu, serta kemiripan dengan objek yang diacu. Sebagaimana pada umumnya terjadi pengelompokkan jenis-jenis motif hias berdasarkan wujudnya (Sumardjo, 2006, 69).

Diketahui bahwa dalam penempatan ukiran dari keempat bilik padi sampel penelitian ini tidak ada keseragaman, baik bentuk motif maupun tempat penerapannya, demikian pula penamaan motifnya. Pada suatu bilik padi ada yang banyak ukirannya, pada bilik padi yang lain ada yang minim. Perbedaan ini disebabkan oleh berbagai faktor, seperti perbedaan creator pelaksana, waktu, tempat, tujuan pembuatan, dan sebagainya. Perbedaan tersebut tentu suatu hal yang wajar, berdasarkan penyebabnya, meskipun demikian ada hal yang hampir sama di antara keempat sampel tersebut, yakni bentuk tiang, teknik pembuatan, motif yang digunakan dan maknanya.
Secara umum motif ukiran yang berkembang di tiga daerah yang telah dipaparkan di muka memiliki persamaan dan perbedaan. Persamaannya seperti bentuk motifnya sama-sama mengambil bentuk tumbuh-tumbuhan dan stilirisasinya. Bentuk motif geometris juga hampir terdapat pada setiap bilik padi, salah satu contohnya adalah bentuk Lung Kangkung atau Keluk Paku. Dalam hal teknik penggarapan juga hampir sama, tetapi ada yang halus dan ada yang kasar, sesuai dengan kondisi pada saat tersebut. Bilik padi di tiga wilayah tersebut sama-sama tidak menggunakan motif bentuk binatang, hanya satu bilik padi yang terdapat motif nama binatang, yakni Ula Gerang, pada bilik padi di Lolo Gedang. Tetapi secara visualisasi tidak menggambarkan ular, hanya liuk dan lekuknya saja yang seperti ular, sementara isian motif tetap mensiratkan bentuk tumbu-tumbuhan.

Seni ukir bilik padi Kerinci, tumbuh dan berkembang dalam masyarakat tradisi, yang hidup secara kolektif dalam dusun-dusun, dinaungi oleh pemerintahan adat. Keseniannya tumbuh dalam kesehajaan dan kesederhanaan sebagai budaya masyarakat pedalaman/pegunungan. Dengan meminjam pendapat Soekiman, ornamen ukiran tersebut setidaknya dilatar belakangi oleh dua faktor, yaitu: pertama, faktor emosi; dan kedua, faktor teknik (Soekiman, 2000: 246). Emosi, dalam seni ukir bilik padi bukanlah emosi yang terkait dengan kepercayaan animisme, seperti karya seni primitif, yang terdapat pada bangnan batu masyarakat Kerinci sebelumnya. Dijelaskan Bastomi, bahwa; pada dasarnya kesenian tradisional adalah kesenian asli yang lahir dengan adanya dorongan emosi dan kehidupan batin yang murni atas dasar pandangan hidup dan kepentingan pribadi masyarakat pendukungnya (Bastomi, 2003, 48).

Berangkat dari pandangan tersebut, apabila dilihat masyarakat Kerinci saat 
melahirkan karya-karya seni tradisi-nya, dengan memvisualisasikan nilai-nilai adat dan religi yang mereka anut, serta diilhami berbagai hal, buah dari kedekatan dengan alam, ke dalam wujud ukiran. Kiranya dapat diuraikan ukiran tersebut selain asli, lahir dari dorongan emosi dan kehidupan batin yang murni juga atas dasar pandangan hidup mereka. Pada masa tersebut masyarakat masih berpegang teguh pada nilai-nilai adat dan ajaran Islam, yang menjadi pandangan hidup mereka. Lebih jauh dijelaskan Bastomi $(2003,48)$, bahwa

Dengan pandangan hidup masyarakat yang telah mantap tak akan goyah dan berubah, namun pandangan hidup dapat berkembang menurut kebutuhannya. Adapun fungsi dan peranan kesenian tradisional bukanlah sesuatu yang beku, melainkan sesuatu yang berkembang sesuai dengan kebutuhan pemiliknya. Perkembangan kesenian tradisional seiring dengan irama pertumbuhan adat budaya masyarakat pemiliknya.

Pandangan hidup masyarakat Kerinci dari dahulu hingga sekarang tidak berubah, di mana semenjak bersentuhan dengan Islam disebutkan Adat Basendi Syara', Syara' Basendi Kitabullah, Adat Berbuhul Sentak, Syarak Berbuhul Mati (Dinas Pariwisata dan Kebudayaan Kerinci, 2003: 28). Adat dan agama yang menjadi landasan pandangan hidup masyarakat Kerinci tersebut tetap, tetapi "peraturan pelaksanaan" dari sesuatu ketentuan adat dapat berubah-ubah sesuai dengan perkembangan zaman dan situasi yang mendesak. Perubahan itu terjadi karena untuk menyesuaikan dari perkembangan zaman dan perkembangan pandangan dari kebijakan yang ada, seperti kata pepatah: Sekali air besar, sekali tepian berubah.
Sementara itu terkait dengan teknik, adalah adanya kemampuan masyarakat Kerinci dalam hal penguasaan bahan atau media yang digunakan, kemudian kemampuan mengolahnya atau membuatnya sehingga melahirkan karya ukiran. Terkait dengan kemampuan teknis, disertai ketersediaan bahan dan peralatan. Berangkat dari faktorfaktor yang melatarbelakangi penciptaannya, tentu ada maksud dan tujuan di balik itu semua. Apabila ditinjau ke belakang, seni ukir pada bilik dalam masyarakat Kerinci pada masa bangunan tersebut masih difungsikan sebagaimana konsep awalnya, maka ukirannya memiliki berbagai fungsi. Berfungsi dalam arti fisik juga dalam tataran nilai-nilai, yang menunjukkan manfaat terhadap masyarakat pendukungnya dalam kehidupan komunal.

\section{PENUTUP}

Lumbung padi di Kerinci disebut bilik padi. Keberadaan bilik padi merupakan kelengkapan dari arsitektur tradisional Kerinci lainnya, yakni rumah larik dan Masjid, sebagai masyarakat yang agraris dalam pemukimam berlarik dan berjajo. Seluruh bagian bilik padi terbuat bahan kayu, serta beberapa bagian dari bambu. Pembangunan dengan teknologi konstruksi tradisional, menggunakan batu umpak atau sendi batu sebagai tumpuan tiang, dan sistem pasak dalam merangkai tiang dengan balok. Bangunan dibuat membesar ke atas. Tiang segi delapan, atap dari lembaran papan (atap sirap), pintu dibuat kecil, dibawah bubungan atap, dengan tangga jantan atau tangga batino yang bisa dibuat permanen atau dibongkar pasang. Bilik padi terdiri dari dua ukuran, yang kecil panjang tiga depa dan lebar dua depa, yang besar panjang empat depa dan lebar dua depa. Tinggi dinding samping dua sampai tiga depa, dan tinggi bubungan atap tiga sampai empat depa. Pada beberapa bagian bangunan diterapkan ukiran. Secara 
umum tidak ada bilik padi yang difinishing atau diwarnai, kecuali beberapa bagian ukiran.

Motif ukiran secara umum berasal dari bentuk tumbuh-tumbuhan, berupa daun dan sulur-suluran. Hampir tidak ditemukan adanya motif bentuk makhluk hidup, hanya penggunaan nama saja, seperti motif Ula Gerang, tetapi visualisasinya tidaklah menggambarkan seekor ular. Sebahagian motif ukiran masif kelanjutan dari pengembangan motif atau gambar-gambar masa prasejarah di bangunan batu. Ukiran pada bilik padi secara umum diterapkan pada tiang, berupa motif Paku Rancah, Kukea Gajeah, Bungea Kemboja, Tigo Takah, Glangglang dan Pahuh Enggang. Pada dinding diterapkan motif Bungea Kemboja. Pada balok bawah diterapkan motif Lung Kangkung Patah Tumbuh Hilang Baganti, Keluk Paku. Pada balok atas diterapkan motif Ula Gerang dan Keluk Paku. Pada ujung kasau diterapkan motif Gadeik-gadeik. Motif diukir denngan teknik yang sederhana menggunakan pahat dan pisau ukir. Menghasilkan ukiran garis, cekung dan cembung, serta permukaan ukiran yang cenderung kasar. Secara umum ukiran tidak diwarnai, hanya beberapa saja yang diwarnai dengan warna merah, putih, hijau, kuning dan hitam.

Bilik padi tradisional Kerinci sebagai salah satu khasanah kekayaan kebudayaan Kerinci, terbentuk bersamaan dengan pendirian rumah Larik dan Masjid. Namun amat disayangkan saat ini hampir punah. Altenatif yang tepat saat ini adalah merevitalisasi bilik padi sesuai dengan kebutuhan masa sekarang. Menjadikan bilik padi berfungsi baru sebagai objek wisata, atau fungsi lain dengan tetap mempertahankan bentuk dan konstruksinya, serta dengan mengembangkan seni ukirnya sebagai elemen estetis pada bangunan modern, seperti perkantoran, museum, hotel, restoran, toko/supermarket, rumah pribadi dan bangunan lainnya. Selain itu pada berbagai produk yang berorientasi kekinian, seperti untuk menghiasi beraneka perabotan rumah tangga, perkantoran, restoran, hotel, juga pada produk-produk cendramata. Dengan mengalihkan penempatan tersebut dapat mempertahankan keberadaan motif hias tradisional Kerinci. Demikian juga nilai-nilai yang sebelumnya dapat terus didengungkan melalui penerapan ke media baru. Sehubungan hal tersebut diharapkan pemerintah dan masyarakat terlibat aktif dalam memberikan dukungan terhadap usahausaha pelestarian dan pengembangan bilik padi dan seni ukirnya, terutama dinas Pariwisata dan Kebudayaan kabupaten Kerinci, dinas pendidikan, dinas perindustrian, dan kepurbakalaan

\section{DAFTAR PUSTAKA}

Bastomi, Suwaji. 2003. Seni Kriya Seni. Semarang: UPT Percetakan dan Penerbitan UNNES PRESS.

Feldman, Edmund Burke. 1967. Art as Image and Idea. New Jersey: Prentice Hall, Inc.

Gustami, SP. 2008. Nukilan Seni Ornamen Indonesia. Yogyakarta: Jurusan Seni Kriya, Fakultas Seni Rupa, ISI Yogyakarta.

Hoop, A. N. J. Th. a Th. van der. 1949. RagamRagam Perhiasan Indonesia. Uitgegeven Door Het: Koninklijk Bataviaasch Genootschap Van Kunsten En Wetenscappen.

Ja'far. 1998/1999. "Laporan Penelitian dan Pengolahan Ragam Hias Daerah Jambi", Laporan penelitian. Jambi: Departemen Pendidikan Dan 
Kebudayaan, Direktorat Jenderal

Kebudayaan-Taman Budaya Jambi.

Kayam, Umar. 1981/1982 "Kreativitas Dalam Seni dan Masyarakat Suatu Dimensi Dalam Proses Pembentukan Budaya Dalam Masyarakat", dalam Analisis Kebudayaan, th II-no 1. Jakarta: Departemen Pendidikan dan Kebudayaan.

Nofrial. 2016. Rumah Etnik Kerinci; Arsitektur dan Seni Ukir. Padang Panjang: LPPMPP ISI Padang Panjang

Soedarso Sp. 2006. Trilogi Seni Penciptaan Eksistensi dan Kegunaan Seni. Yogyakarta: BP ISI Yogyakarya.

Sumardjo, Jakob. 2006. Estetika Paradoks. Bandung: Sunan Ambu Press.

Yohanes Suwanto, dkk. 1999. Laporan Penelitian: Istilah Alat-Alat Rumah Tangga dan Perkembangan di KotaSurakarta Pendekatan Etnolinguistik. Surakarta: Fakultas Sastra dan Seni Rupa Universitas Sebelas Maret.

Williams, Raymond. 1981. Culture. Glasgow: Fortana Paperbacks.

Wiyoso, Dkk. 1981/1982. Album Seni Budaya Jambi. Jakarta: Depdikbud- Dirjen BudProyek Media Kebudayaan.

2003. Adat Dan Budaya Kerinci. Kerinci: Dinas Pariwisata dan Kebudayaan Kabupaten Kerinci.

Zakaria, Iskandar. 1984 "Tambo Sakti Alam Kerinci 2". Kerinci (tidak diterbitkan).
Nara Sumber:

H. Alimin Depati (66 th), pensiunan PNS, tokoh adat Sungai Penuh, wawancara tanggal 28 Juli 2008 dan 27 Maret 2019, Dusun Baru, Kota Sungai Penuh, Jambi.

Kamarudin (72 th), tokoh masyarakat, wawancara tanggal 5 Maret 2019, Dusun Baru Siulak, Kecamatan Siulak, Kerinci, Jambi.

M. Wahid Depati Jagung Tuo Susun Negri (73 th), pemuka adat Siulak, wawancara tanggal 26 Maret 2019, Koto Beringin Siulak, kecamatan Siulak, Kerinci, Jambi.

Rahimna (71 th), tokoh masyarakat, wawancara tanggal 8 Maret 2019, Koto Tuo, desa Koto Tengah, Seleman, kecamatan Danau Kerinci, Kerinci. 